Prepared in cooperation with the Harris-Galveston Subsidence District, City of Houston, Fort Bend Subsidence District, Lone Star Groundwater Conservation District, and Brazoria County Groundwater Conservation District

\title{
Status of Groundwater-Level Altitudes and Long-Term Groundwater-Level Changes in the Chicot, Evangeline, and Jasper Aquifers, Houston-Galveston Region, Texas, 2018
}

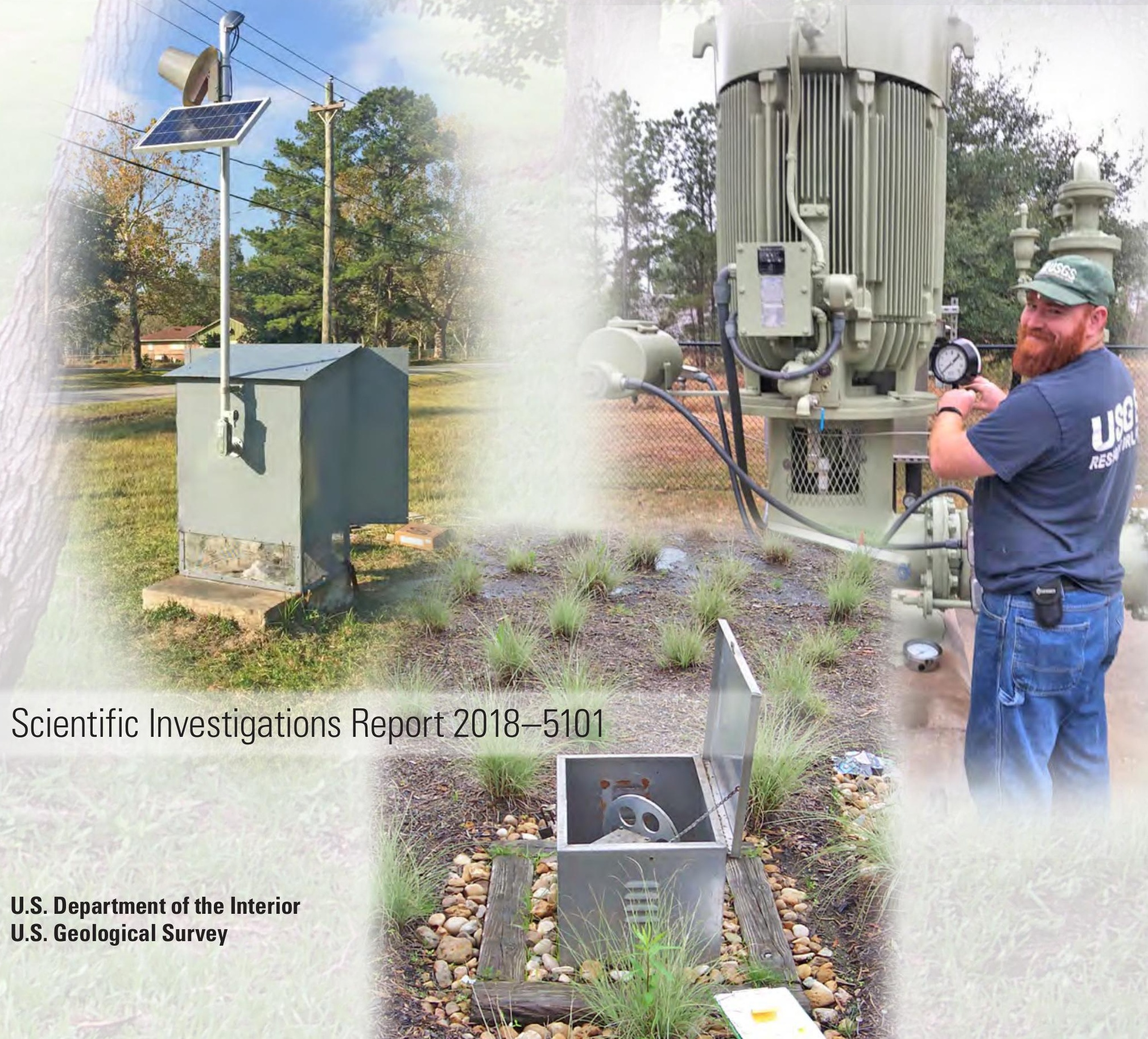


Cover. Front, clockwise: Monitoring well at U.S. Geological Survey (USGS) site 292338095063601 (station KH-65-40-707) in Galveston County, Texas. USGS hydrologic technician measuring a well in Montgomery County, Texas, January 2018. Monitoring well at USGS site 301228095272501 (station TS-60-53-516) in Montgomery County, Texas. 


\section{Status of Groundwater-Level Altitudes and Long-Term Groundwater-Level Changes in the Chicot, Evangeline, and Jasper Aquifers, Houston-Galveston Region, Texas, 2018}

By Sachin D. Shah, Jason K. Ramage, and Christopher L. Braun

Prepared in cooperation with the Harris-Galveston Subsidence District, City of Houston, Fort Bend Subsidence District, Lone Star Groundwater

Conservation District, and Brazoria County Groundwater Conservation District

Scientific Investigations Report 2018-5101 


\section{U.S. Department of the Interior \\ RYAN K. ZINKE, Secretary}

\section{U.S. Geological Survey James F. Reilly II, Director}

\section{U.S. Geological Survey, Reston, Virginia: 2018}

For more information on the USGS - the Federal source for science about the Earth, its natural and living resources, natural hazards, and the environment-visit https://www.usgs.gov or call 1-888-ASK-USGS.

For an overview of USGS information products, including maps, imagery, and publications, visit https://store.usgs.gov.

Any use of trade, firm, or product names is for descriptive purposes only and does not imply endorsement by the U.S. Government.

Although this information product, for the most part, is in the public domain, it also may contain copyrighted materials as noted in the text. Permission to reproduce copyrighted items must be secured from the copyright owner.

Suggested citation:

Shah, S.D., Ramage, J.K., and Braun, C.L., 2018, Status of groundwater-level altitudes and long-term groundwaterlevel changes in the Chicot, Evangeline, and Jasper aquifers, Houston-Galveston region, Texas, 2018: U.S. Geological Survey Scientific Investigations Report 2018-5101, 18 p., https://doi.org/10.3133/sir20185101.

ISSN 2328-031X (print)

ISSN 2328-0328 (online)

ISBN 978-1-4113-4250-7 


\section{Acknowledgments}

The authors thank the owners and operators of wells throughout the study area for granting access and providing pertinent information that expedited data-collection activities.

Additionally, the authors gratefully acknowledge the following U.S. Geological Survey colleagues for assisting in collecting groundwater-level data outside of normal duty hours as necessary and for assisting in processing and analyzing the large amount of resulting data within an abbreviated period: Dexter W. Brown, Robert H. Ellis, Eric M. Boeding, Jeff Sievers, Keith E. Mecum, Lisa L. Ashmore, Mackenzie K. Mullins, and Jason D. Payne. 



\section{Contents}

Abstract

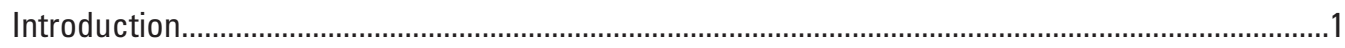

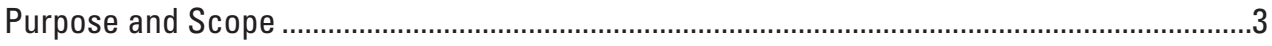

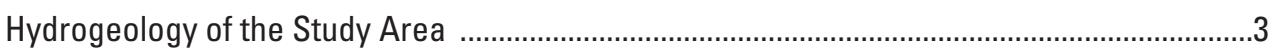

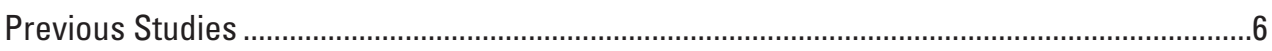

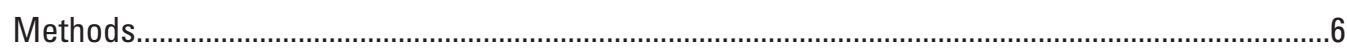

Groundwater-Level Measurements................................................................................6

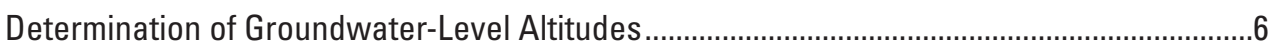

Depicting Long-Term Groundwater-Level Changes.................................................................

Groundwater-Level Altitudes and Long-Term Groundwater-Level Changes....................................7

Chicot Aquifer

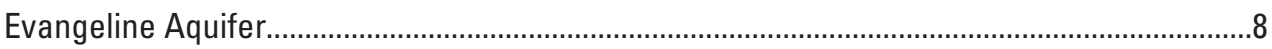

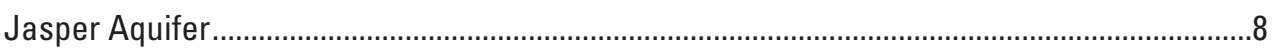

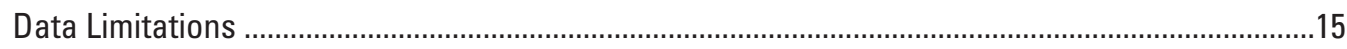

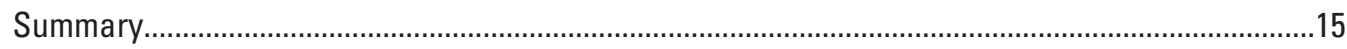

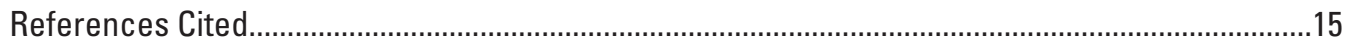

\section{Figures}

1. Map showing locations of groundwater regulatory districts; approximate trace of hydrogeologic section $A-A^{\prime}$; and outcrops and updip limits of the aquifers in the Gulf Coast aquifer system in the Houston-Galveston region

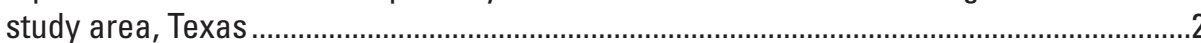

2. Hydrogeologic cross section $A-A^{\prime}$ of the Gulf Coast aquifer system in Grimes, Montgomery, Harris, and Galveston Counties, Texas. 2

3. Stratigraphic column showing geologic and hydrogeologic units of the Gulf Coast aquifer system in the Houston-Galveston region study area, Texas

Map showing approximate 2018 groundwater-level altitudes and updip limit of the Chic ot aquifer, Houston-Galveston region, Texas

5. Map showing approximate 1977-2018 groundwater-level changes in the Chicot aquifer, Houston-Galveston region, Texas.

6. Map showing approximate $\mathbf{2 0 1 8}$ groundwater-level altitudes and updip limit of the Evangeline aquifer, Houston-Galveston region, Texas.

7. Map showing approximate 1977-2018 groundwater-level changes in the Evangeline aquifer, Houston-Galveston region, Texas.

8. Map showing approximate 2018 groundwater-level altitudes and updip limit of the Jasper aquifer, Houston-Galveston region, Texas .

9. Map showing approximate $2000-18$ groundwater-level changes in the Jasper aquifer, Houston-Galveston region, Texas 


\section{Conversion Factors}

U.S. customary units to International System of Units

\begin{tabular}{|c|c|c|}
\hline Multiply & By & To obtain \\
\hline \multicolumn{3}{|c|}{ Length } \\
\hline foot $(\mathrm{ft})$ & 0.3048 & meter $(\mathrm{m})$ \\
\hline$\underline{\text { mile }(\mathrm{mi})}$ & 1.609 & kilometer $(\mathrm{km})$ \\
\hline \multicolumn{3}{|c|}{ Area } \\
\hline square mile $\left(\mathrm{mi}^{2}\right)$ & 2.590 & square kilometer $\left(\mathrm{km}^{2}\right)$ \\
\hline \multicolumn{3}{|c|}{ Transmissivity } \\
\hline foot squared per day $\left(\mathrm{ft}^{2} / \mathrm{d}\right)$ & 0.09290 & meter squared per day $\left(\mathrm{m}^{2} / \mathrm{d}\right)$ \\
\hline
\end{tabular}

International System of Units to U.S. customary units

\begin{tabular}{|c|c|c|}
\hline Multiply & By & To obtain \\
\hline \multicolumn{3}{|c|}{ Length } \\
\hline meter $(\mathrm{m})$ & 3.281 & foot $(\mathrm{ft})$ \\
\hline meter $(\mathrm{m})$ & 1.094 & yard (yd) \\
\hline \multicolumn{3}{|c|}{ Mass } \\
\hline milligram (mg) & 0.00003527 & ounce, avoirdupois (oz) \\
\hline
\end{tabular}

Vertical coordinate information is referenced to either the National Geodetic Vertical Datum of 1929 (NGVD 29) or the North American Vertical Datum of 1988 (NAVD 88).

Horizontal coordinate information is referenced to the North American Datum of 1983 (NAD 83). 


\title{
Status of Groundwater-Level Altitudes and Long-Term Groundwater-Level Changes in the Chicot, Evangeline, and Jasper Aquifers, Houston-Galveston Region, Texas, 2018
}

\author{
By Sachin D. Shah, Jason K. Ramage, and Christopher L. Braun
}

\section{Abstract}

Since the early 1900 s, most of the groundwater withdrawals in the Houston-Galveston region, Texas, have been from the three primary aquifers that compose the Gulf Coast aquifer system - the Chicot, Evangeline, and Jasper aquifers. Withdrawals from these aquifers are used for municipal supply, industrial, and irrigation purposes. This report, prepared by the U.S. Geological Survey in cooperation with the Harris-Galveston Subsidence District, City of Houston, Fort Bend Subsidence District, Lone Star Groundwater Conservation District, and Brazoria County Groundwater Conservation District, is one in an annual series of reports depicting the status of groundwater-level altitudes and long-term groundwater-level changes in the Chicot, Evangeline, and Jasper aquifers in the Houston-Galveston region. This report contains regional-scale maps depicting approximate 2018 groundwater-level altitudes (represented by measurements made during December 2017 through March 2018) and long-term groundwater-level changes for the Chicot, Evangeline, and Jasper aquifers.

In 2018, groundwater-level-altitude contours for the Chicot aquifer ranged from 200 feet (ft) below the North American Vertical Datum of 1988 (hereinafter referred to as "datum") to $200 \mathrm{ft}$ above datum. The 1977-2018 groundwaterlevel-change contours for the Chicot aquifer depict a large area of decline in groundwater-level altitudes (120 ft) in northwestern Harris County. The largest rise in groundwaterlevel altitudes in the Chicot aquifer from 1977 to 2018 (180 ft) was in southeastern Harris County.

Groundwater-level-altitude contours for the Evangeline aquifer ranged from $250 \mathrm{ft}$ below datum to $200 \mathrm{ft}$ above datum in 2018. The 1977-2018 groundwater-level-change contours for the Evangeline aquifer depict broad areas where groundwater-level altitudes either declined or rose. The largest decline in groundwater-level altitudes $(320 \mathrm{ft})$ was in southern Montgomery County. The largest rise in groundwater-level altitudes in the Evangeline aquifer from 1977 to 2018 (240 ft) was in southeastern Harris County.
In 2018, groundwater-level-altitude contours for the Jasper aquifer ranged from $200 \mathrm{ft}$ below datum to $200 \mathrm{ft}$ above datum. The 2000-18 groundwater-level-change contours for the Jasper aquifer depict groundwater-level declines throughout most of the study area where groundwater-level-altitude data from the Jasper aquifer were collected, with the largest decline (200 ft) in southern Montgomery County.

\section{Introduction}

The Houston-Galveston region, Texas, consists of Harris, Galveston, Fort Bend, Montgomery, Brazoria, Chambers, Grimes, Liberty, San Jacinto, Walker, and Waller Counties (fig. 1). Groundwater withdrawn from the three primary aquifers that compose the Gulf Coast aquifer system - the Chicot, Evangeline, and Jasper aquifers - has been the primary source of water for municipal supply, commercial and industrial use, and irrigation in the Houston-Galveston region since the early 1900s (Kasmarek and Robinson, 2004). Prior to 1975, the withdrawal of groundwater from the Chicot and Evangeline aquifers was unregulated, and water levels in the aquifers were declining, resulting in subsidence (Coplin and Galloway, 1999). By 1977, the withdrawals had resulted in groundwater-levelaltitude declines in southeastern Harris County of 300 and 350 feet (ft) below the North American Vertical Datum of 1988 (NAVD 88) in the Chicot and Evangeline aquifers, respectively (Gabrysch, 1979).

To regulate and reduce groundwater withdrawals in Harris and Galveston Counties, the 64th Texas State Legislature authorized the establishment of the HarrisGalveston Subsidence District (HGSD) in 1975 (HarrisGalveston Subsidence District, 2013). After establishing the HGSD, the Texas State Legislature established an additional subsidence district (Fort Bend Subsidence District [FBSD]) and two groundwater conservation districts (Lone Star Groundwater Conservation District [LSGCD] and Brazoria County Groundwater Conservation District [BCGCD]) in the Houston-Galveston region to enable the regulation of groundwater withdrawals within their respective jurisdictions. 


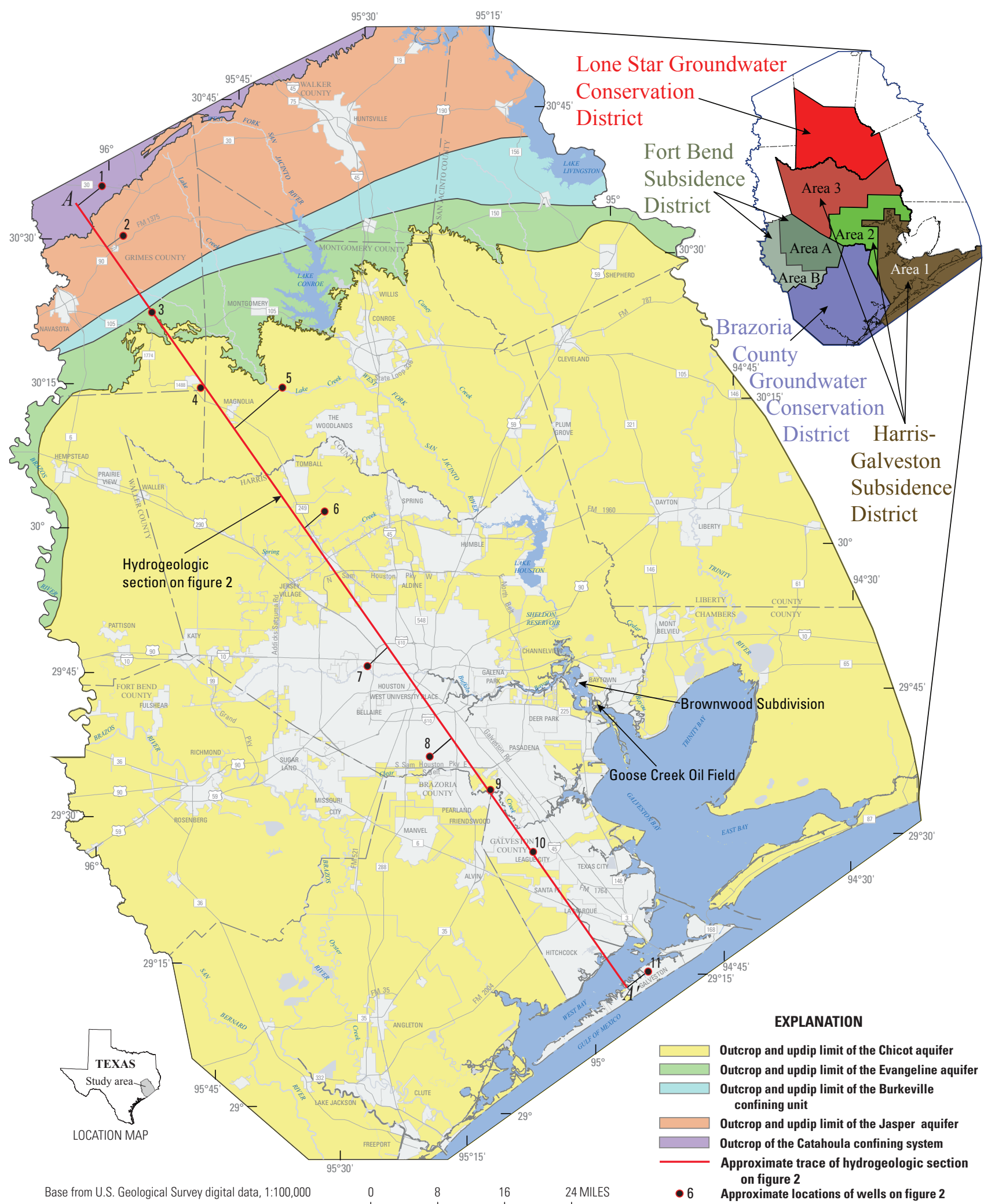

Universal Transverse Mercator projection, Zone 15

North American Datum of 1983

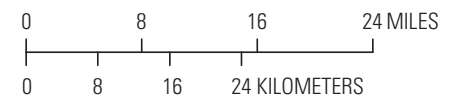

Note: Aquifer data from Strom and others, 2003a, b, c; Kasmarek and Robinson, 2004

Figure 1. Locations of groundwater regulatory districts; approximate trace of hydrogeologic section $A-A^{\prime}$; and outcrops and updip limits of the aquifers in the Gulf Coast aquifer system in the Houston-Galveston region study area, Texas (modified from Strom and others, 2003a, b, c; Kasmarek and Robinson, 2004). 
The FBSD was established by the 71st Texas State Legislature in 1989, the LSGCD was established by the 77th Texas State Legislature in 2001, and the BCGCD was established by the 78th Texas State Legislature in 2003 (Kasmarek and Ramage, 2017). Regulatory plans to gradually decrease groundwater withdrawals (in conjunction with increased usage of alternative surface-water supplies) are currently (2018) being phased in throughout the study area; the current groundwater management plans of each district are available on their respective websites (Brazoria County Groundwater Conservation District, 2012; Fort Bend Subsidence District, 2013; Harris-Galveston Subsidence District, 2013; Lone Star Groundwater Conservation District, 2013). Groundwater withdrawals are currently (2018) not being regulated by a groundwater conservation district in two counties in the Houston-Galveston region (Liberty and Chambers Counties).

Since the 1970s, the U.S. Geological Survey (USGS), in cooperation with the HGSD and with the additional subsidence and groundwater-conservation districts (FBSD, LSGCD and BCGCD) as they became operational, has been monitoring groundwater-level altitudes and publishing reports on the status of groundwater-level altitudes and long-term groundwater-level changes in the Houston-Galveston region. An extensive well-monitoring network was first established by the USGS in 1977, and water-level data were collected and used to create the first published water-level-altitude maps of the Chicot and Evangeline aquifers in the Houston-Galveston region (Gabrysch, 1979). A comprehensive water-level-

altitude report for the Chicot and Evangeline aquifers was first published by the USGS in 1991 (Barbie and others, 1991). The USGS also first published a water-level-altitude map in 2001 of the Jasper aquifer in the Houston-Galveston region (Coplin, 2001). Additional information on the history of groundwaterlevel altitude monitoring and of the USGS reports published to document groundwater-level altitudes and changes in groundwater-level altitudes in the Houston-Galveston region is provided by Kasmarek and Ramage (2017).

\section{Purpose and Scope}

The purpose of this report, prepared by the USGS in cooperation with the HGSD, City of Houston, FBSD, LSGCD, and BCGCD, is to depict groundwater-level altitudes and long-term groundwater-level changes in the Chicot, Evangeline, and Jasper aquifers in the Houston-Galveston region. An overview of the hydrogeology of the study area is provided. Regional-scale maps depicting contoured groundwater-level altitudes for 2018 and depicting long-term groundwater-level changes in the Chicot and Evangeline aquifers (1977-2018) and the Jasper aquifer (2000-18) are featured. Individual groundwater-level altitudes measured at each well for all three aquifers that were assessed (Chicot, Evangeline, and Jasper aquifers) and associated metadata are available for download in a companion data release (Shah and Ramage, 2018a, b).

\section{Hydrogeology of the Study Area}

The following overview of the hydrogeology of the study area is modified from Kasmarek and Ramage (2017). The three primary aquifers in the Gulf Coast aquifer system in the Houston-Galveston region study area (the Chicot, Evangeline, and Jasper aquifers) are composed of laterally discontinuous deposits of gravel, sand, silt, and clay (Baker, 1979). The youngest and uppermost aquifer, the Chicot aquifer, consists of Holocene- and Pleistocene-age sediments; the underlying Evangeline aquifer consists of Pliocene- and Miocene-age sediments; and the oldest and most deeply buried of the three aquifers, the Jasper aquifer, consists of Miocene-age sediments (fig. 2) (Baker, 1979, 1986). The hydrogeologic cross section $A-A^{\prime}$ (figs. 1 and 2) of the Gulf Coast aquifer system extends through the Houston-Galveston region from northwestern Grimes County southeastward through Montgomery and Harris Counties before terminating at the coast in Galveston County.

The percentage of clay and other fine-grained clastic material generally increases with depth downdip (Baker, 1979). Through time, geologic and hydrologic processes created accretionary sediment wedges (stacked sequences of sediments) more than 7,600 ft thick at the coast (fig. 2) (Chowdhury and Turco, 2006). The sediments composing the Gulf Coast aquifer system were deposited by fluvial-deltaic processes and subsequently were eroded and redeposited (reworked) by worldwide episodic changes in sea level that occurred as a result of oscillations between glacial and interglacial climate conditions (Lambeck and others, 2002). The Gulf Coast aquifer system consists of hydrogeologic units that dip and thicken from northwest to southeast (fig. 2); the aquifers thus crop out in bands inland from and approximately parallel to the coast and become progressively more deeply buried and confined toward the coast (fig. 2) (Kasmarek, 2013). The Burkeville confining unit is stratigraphically positioned between the Evangeline and Jasper aquifers (fig. 2), thereby restricting groundwater flow between these two aquifers. There is no confining unit between the Chicot and Evangeline aquifers (fig. 2); therefore, these two aquifers are hydraulically connected, which allows groundwater flow between them. Because of this hydraulic connection, groundwater-level changes that occur in one aquifer can affect groundwater levels in the adjoining aquifer (Kasmarek and Robinson, 2004). Supporting evidence of the interaction of groundwater flow between the Chicot and Evangeline aquifers is demonstrated by determining the differences between long-term groundwater-level-change maps, which indicate that the areas where water levels have risen or declined are approximately spatially coincident.

Hydraulic properties of the Chicot aquifer do not differ appreciably from those of the hydrogeologically similar Evangeline aquifer but can be differentiated on the basis of hydraulic conductivity (Carr and others, 1985, p. 10). From aquifer-test data, Meyer and Carr (1979) estimated that the transmissivity of the Chicot aquifer ranges from 3,000 to 25,000 feet squared per day ( $\left.\mathrm{ft}^{2} / \mathrm{d}\right)$ and that the transmissivity of the Evangeline aquifer ranges from 3,000 to $15,000 \mathrm{ft}^{2} / \mathrm{d}$. 


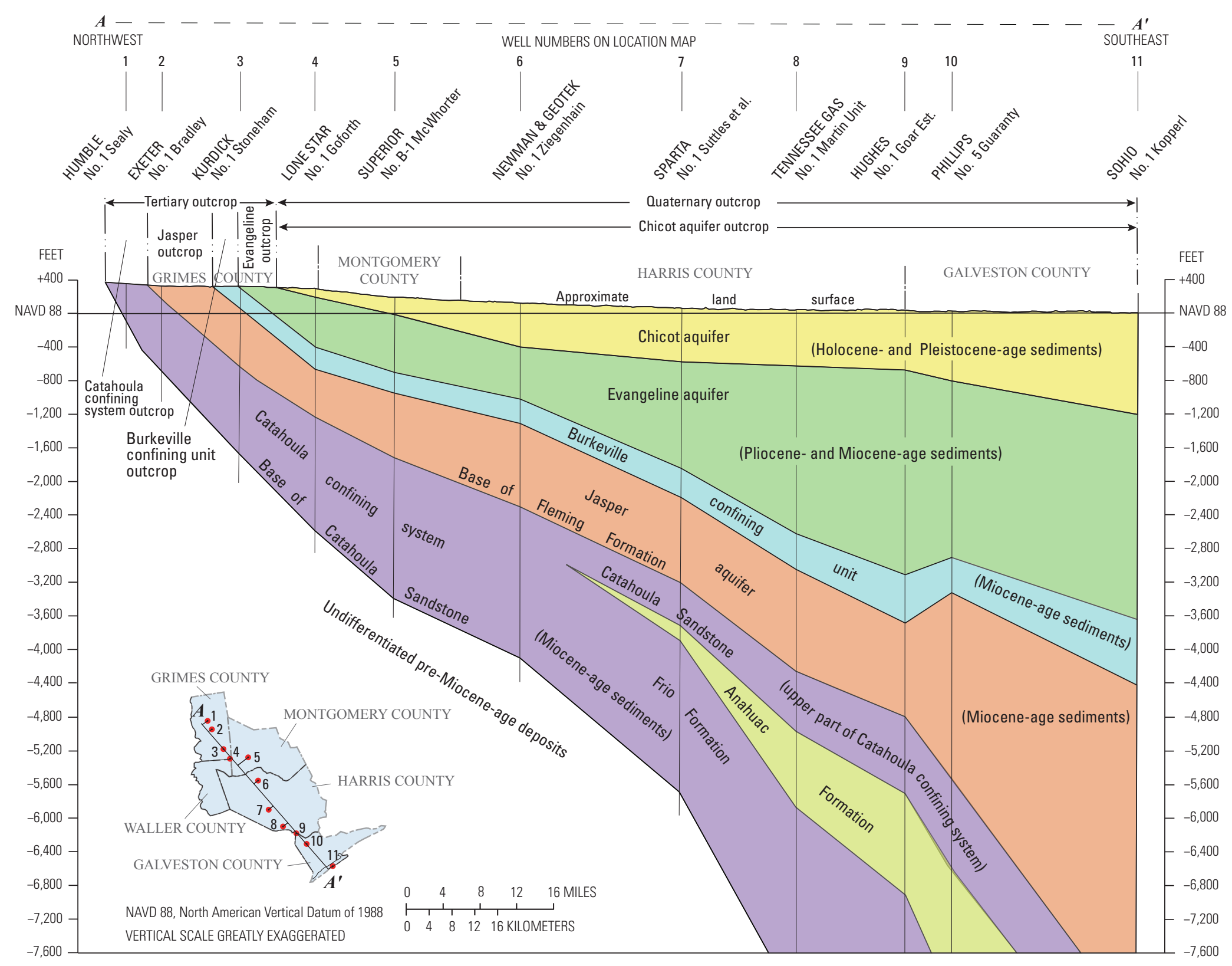

Figure 2. Hydrogeologic cross section $A-A^{\prime}$ of the Gulf Coast aquifer system in Grimes, Montgomery, Harris, and Galveston Counties, Texas (modified from Baker, 1979, fig. 4). 
The Chicot aquifer outcrops and extends inland from the Gulf of Mexico coast and terminates at the northernmost updip limit of the aquifer. Proceeding updip and inland of the Chicot aquifer, the older hydrogeologic units - the Evangeline aquifer, the Burkeville confining unit, the Jasper aquifer, and the Catahoula confining system-sequentially outcrop (fig. 1). In the updip areas of the Jasper aquifer, the aquifer can be differentiated from the Evangeline aquifer on the basis of the depths to water below land-surface datum, which are shallower (closer to land surface) in the Jasper aquifer compared to those in the Evangeline aquifer. Additionally, in the downdip parts of the aquifer system, the Jasper aquifer can be differentiated from the Evangeline aquifer on the basis of stratigraphic position relative to the elevation of the Burkeville confining unit (figs. 2 and 3).
Precipitation falling on the land surface overlying these aquifers returns to the atmosphere as evapotranspiration, discharges to streams, or infiltrates as groundwater recharge to the unconfined updip sediments composing the aquifers. The infiltrating water moves downgradient toward the coast, reaching the intermediate and deep zones of the aquifers southeastward of the outcrop areas, where it can be withdrawn and discharged by wells or is naturally discharged by diffuse upward leakage in topographically low areas near the coast (Kasmarek and Robinson, 2004). Water in the coastal, deep zones of the aquifers is denser, and this higher density water causes the fresher, lower density water that has not been captured and withdrawn by wells to be redirected as diffuse upward leakage to shallow zones of the confined downdip areas of the aquifer system (Kasmarek and Robinson, 2004).

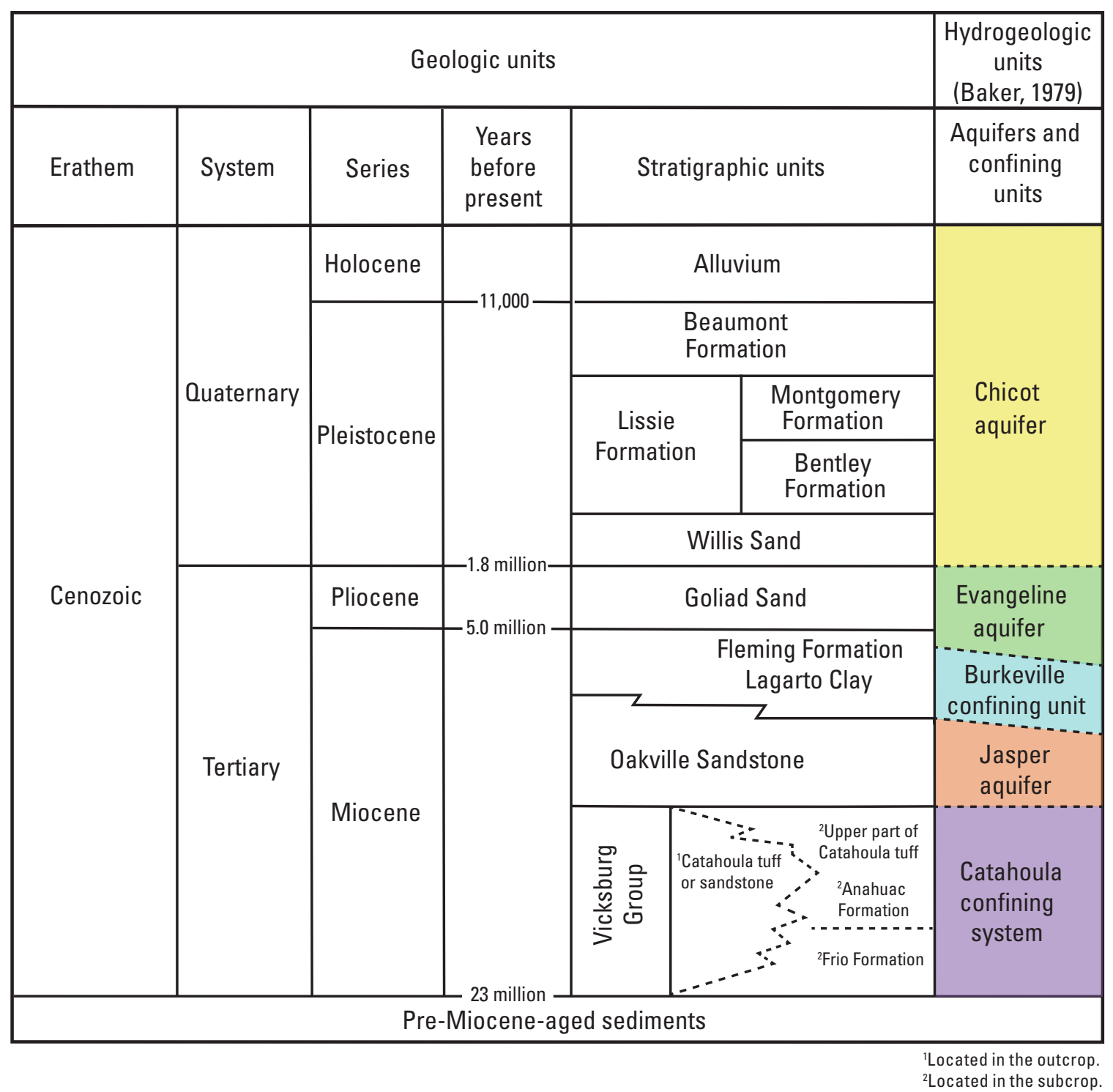

Figure 3. Geologic and hydrogeologic units of the Gulf Coast aquifer system in the Houston-Galveston region study area, Texas (modified from Sellards and others, 1932; Baker, 1979; Meyer and Carr, 1979). 


\section{Previous Studies}

An extensive well-monitoring network was established by 1977 , and groundwater-level data were collected and used to create the first published groundwater-level-altitude maps of the Chicot and Evangeline aquifers in the HoustonGalveston region (Gabrysch, 1979). The FBSD adopted its groundwater management plan in 1990 (Fort Bend Subsidence District, 2013), and in cooperation with the FBSD, an increased number of wells were inventoried by the USGS in Fort Bend, Harris, Brazoria, and Waller Counties in 1989 and 1990. A more comprehensive groundwater-level-altitude report for the Chicot and Evangeline aquifers was published by the USGS in 1991 (Barbie and others, 1991) and was revised in 1997 when updated well data became available (Kasmarek, 1997). Similarly, after the establishment of the LSGCD in 2001, the USGS started publishing a groundwater-level-altitude map of the Jasper aquifer in the Houston-Galveston region (primarily Montgomery County) (Coplin, 2001). In 2004, 2006, and 2007, as additional wells with reliable groundwater-level data were inventoried, revised groundwater-level-altitude maps for the Jasper aquifer were prepared (Kasmarek and Lanning-Rush, 2004; Kasmarek and others, 2006; Kasmarek and Houston, 2007). In comparison to groundwater-level-altitude maps in the 2001 (Coplin, 2001) and 2004 (Kasmarek and LanningRush, 2004) reports, the 2007 groundwater-level-altitude map (Kasmarek and Houston, 2007) was the most comprehensive for the Jasper aquifer in the study area prepared to date at that time. Since 2007, comprehensive maps for the Jasper aquifer have been included in the annual series of reports that depict groundwater-level altitudes and groundwater-level changes in the Chicot, Evangeline, and Jasper aquifers in the HoustonGalveston region (Kasmarek and Houston, 2008; Kasmarek and others, 2010, 2011, 2012, 2013, 2014, 2015, 2016; Johnson and others, 2011; Kasmarek and Ramage, 2017).

\section{Methods}

This section describes the methods used to collect and process groundwater-level data used in this report, determine groundwater-level altitudes, and depict long-term groundwater-level changes in the study area. These methods are similar to those described in previous reports by Gabrysch (1979), Kasmarek and Houston (2007), and Kasmarek and Ramage (2017).

\section{Groundwater-Level Measurements}

Groundwater-level data were obtained during December 2017 through March 2018 from observation wells by measuring the depth to water below land-surface datum at each well to represent the 2018 groundwater-level altitudes of the Chicot, Evangeline, and Jasper aquifers. Most of the measurements were made by USGS personnel by using a calibrated steel tape, airline, or electric water-level tape in accordance with methods described in Cunningham and Schalk (2011). In 2018, 25 measurements representing about 4 percent of the total number of all groundwater-level measurements were furnished by industrial entities and powerplants operating within the study area that use water for hydrocarbon processing and electrical power generation, respectively. The furnished water levels were typically measured by using air pressure to determine the saturated thickness above the pump intake, and multiple pressure measurements were usually collected as a quality-control measure. Air pressure measurements tend to provide less precision than do measurements made with either a steel tape or electric tape; therefore, all furnished measurements were rounded to the nearest foot. All collected and compiled water-level measurements were carefully reviewed by USGS personnel and loaded into the USGS National Water Information System (NWIS) (U.S. Geological Survey, 2018b). Protocols for the collection and review of groundwater-level data were in accordance with the USGS Texas Water Science Center internal document "Quality Assurance and Data Management Plan for Groundwater Activities" dated August 2017 (section 5.0, "Data Collection," and section 6.0, "Data Review and Processing" [Christopher L. Braun, U.S. Geological Survey, written commun., 2017]).

Most of the measured wells were being pumped at least once daily and some more frequently during the period of this study. Well pumps were therefore turned off for at least 1 hour before the groundwater-level measurements were made in order to obtain a groundwater-level measurement that approximated the static conditions within the aquifer. Antecedent withdrawal rates and pumping status of nearby wells were not always known, however, and in such instances could have affected the representativeness of the groundwaterlevel data that were collected. To ensure that the recorded groundwater-level measurement was accurate, at least two groundwater-level measurements were made at each well while the well was not being pumped. After the groundwaterlevel-measurement data were collected, they were thoroughly evaluated and incorporated into a geographic information system (GIS) as point-data layers and subsequently used for the construction of groundwater-level-altitude and groundwater-level-change maps. The groundwater-level measurements collected or provided for this study are compiled in Shah and Ramage (2018a).

\section{Determination of Groundwater-Level Altitudes}

The 2018 regional-scale depictions of groundwaterlevel altitudes presented in this report were derived from groundwater-level-measurement data collected throughout the 11-county study area from December 2017 through March 2018 (water levels usually are higher during these months compared to the rest of the year). Groundwater-level-altitude data were calculated by subtracting the groundwater-level 
measurement from the land-surface elevation at each well referenced to NAVD 88 (National Oceanic and Atmospheric Administration, 2008). Prior to 2016, groundwater-level altitudes published in this annual series of USGS reports were referenced to either the National Geodetic Vertical Datum of 1929 or NAVD 88.

The accuracy of land-surface elevation data at wells used in the annual series of reports has gradually improved over time as digital elevation models have supplanted traditional methods of determining land-surface elevations from topographic maps. The most accurate land-surface data available were used by the USGS for each historical annual depiction of groundwater-level altitudes in the study area. To determine land-surface elevations in 2018, a corresponding land-surface datum was obtained for each well by using a USGS National Geospatial Program 1-meter digital elevation model (DEM) that provides three-dimensional elevation values referenced to NAVD 88 (Arundel and others, 2015; U.S. Geological Survey, 2018a). The height above land surface of the measuring point at each well was measured with an engineering ruler. In 1977, land-surface elevation data were calculated from USGS 1:24,000-scale 7.5-minute topographic quadrangle maps for the Gulf of Mexico coastal area, which have a 5-ft contour as described in Gabrysch (1979), thereby providing an accuracy of $2.5 \mathrm{ft}$. The DEM method used to determine land-surface elevation in 2018 provides an accuracy of $0.5 \mathrm{ft}$.

The 2018 groundwater-level altitudes measured in wells completed in the Chicot, Evangeline, and Jasper aquifers are depicted on contour maps with $50-\mathrm{ft}$ contour intervals. The groundwater-level-altitude contours are approximate, regional-scale depictions of the water levels in wells in the Chicot, Evangeline, and Jasper aquifers, and the areal extents and locations of these contours represent the combined effects of total groundwater withdrawals from all groundwater wells screened in the Gulf Coast aquifer system.

\section{Depicting Long-Term Groundwater- Level Changes}

Maps depicting changes in groundwater-level altitudes in the Chicot, Evangeline, and Jasper aquifers were constructed for the period of record available for each of the aquifers; data are from 1977-2018 for the Chicot and Evangeline aquifers and from 2000-18 for the Jasper aquifer. Groundwater-level changes were computed as the difference between groundwater-level altitudes at each well for which a groundwater-level measurement was made in 1977 or 2000 and in 2018. For wells measured in 2018 that had no corresponding measurement in 1977 or 2000, a GIS raster (gridded surface) (Worboys, 1995) was created from published 1977 (Gabrysch, 1979) or 2000 (Kasmarek and Houston, 2007) groundwater-level-altitude contours. The maps were constructed by contouring the set of mapped point values, computed either as the difference in groundwater-level altitude at each well for which a groundwater-level measurement was made in 2018 and in the historical year or as the difference in groundwater-level altitude at that point in 2018 and the groundwater-level altitude on a gridded surface of the historical year groundwater-level-altitude map (Gabrysch, 1979;

Kasmarek and Houston, 2007). Gridded-surface values (rather than actual measured values) for the historical year were used to compute differences (mapped point values) because many of the wells measured in 1977 or 2000 have been destroyed or were not measured in 2018. For the subset of wells measured both in 2018 and in the historical year, the mapped point values used were the differences in groundwater-level-altitude values between 2018 and the historical year rather than the differences between the 2018 groundwater-level-altitude values and the gridded-surface values from the historical year. The datasets of groundwater-level-change values (difference between 2018 and historical year groundwater-level-altitude values) are available in Shah and Ramage (2018a, b).

\section{Groundwater-Level Altitudes and Long- Term Groundwater-Level Changes}

Groundwater-level-altitude and long-term groundwaterlevel-change maps were constructed for the Chicot, Evangeline, and Jasper aquifers in the study area (figs. 4-9). Whereas the aquifer maps in this report depict approximate groundwaterlevel altitudes for 2018 (figs. 4, 6, and 8) by using 50-ft contour intervals, 20 -ft contour intervals were used to depict groundwater-level changes for 1977-2018 in the Chicot aquifer (fig. 5), 40-foot contour intervals were used for 1977-2018 in the Evangeline aquifer (fig. 7), and 20-foot contour intervals were used for 2000-18 in the Jasper aquifer (fig. 9). All groundwater-level-altitude contours in this report are considered approximate. Locations of wells used to construct 2018 groundwater-level-altitude maps for the Chicot, Evangeline, and Jasper aquifers are presented in Shah and Ramage (2018a, b).

\section{Chicot Aquifer}

Groundwater-level-measurement data from 172 wells were used to depict the 2018 groundwater-level-altitude contours for the Chicot aquifer (fig. 4). In 2018, groundwater-level-altitude contours for the Chicot aquifer ranged from $200 \mathrm{ft}$ below NAVD 88 (hereinafter referred to as "datum") in the western part of Houston to $200 \mathrm{ft}$ above datum west of Conroe, Tex.

The largest decline in groundwater-level altitudes $(120 \mathrm{ft})$ indicated by the 1977-2018 groundwater-level-change contours for the Chicot aquifer was in northwestern Harris County near Jersey Village, Tex. (fig. 5). The largest rise in groundwaterlevel altitudes in the Chicot aquifer from 1977 to 2018 (180 ft) was in southeastern Harris County between Deer Park, Tex., and Baytown, Tex. (fig. 5). 


\section{Evangeline Aquifer}

Groundwater-level-measurement data from 332 wells were used to depict the approximate 2018 groundwater-levelaltitude contours for the Evangeline aquifer (fig. 6). In 2018, groundwater-level altitudes in the Evangeline aquifer ranged from $250 \mathrm{ft}$ below datum in three locations (northwestern Houston, near the Jersey Village area, and between Spring, Tex., and The Woodlands, Tex.) to $200 \mathrm{ft}$ above datum north of Montgomery, Tex., and in the southeastern part of Grimes County.

The 1977-2018 groundwater-level-change contours for the Evangeline aquifer (fig. 7) depict broad areas where groundwater-level altitudes either declined or rose. The largest decline in groundwater-level altitudes in the Evangeline aquifer from 1977 to 2018 (320 ft) was in southern Montgomery County, near The Woodlands (fig. 7). The largest rise in groundwater-level altitudes in the Evangeline aquifer from 1977 to 2018 (240 ft) was in southeastern Harris County along Buffalo Bayou near Galena Park, Tex. (fig. 7).

\section{Jasper Aquifer}

Groundwater-level-measurement data from 108 wells were used to depict the approximate 2018 groundwaterlevel-altitude contours for the Jasper aquifer (fig. 8). In 2018, groundwater-level-altitude contours for the Jasper aquifer ranged from $200 \mathrm{ft}$ below datum near The Woodlands to $200 \mathrm{ft}$ above datum in northeastern Grimes County, northwestern Montgomery County, and southwestern Walker County (fig. 8).

Whereas annual groundwater-level-altitude data have been collected since 1977 from wells completed in the Chicot and Evangeline aquifers, annual groundwater-levelaltitude data have been collected from wells completed in the Jasper aquifer since only 2000 . The 2000-18 groundwaterlevel-change contours for the Jasper aquifer (fig. 9) depict groundwater-level declines throughout most of the study area where groundwater-level-altitude data from the Jasper aquifer were collected, with the largest decline $(200 \mathrm{ft})$ in southern Montgomery County between Spring and The Woodlands.

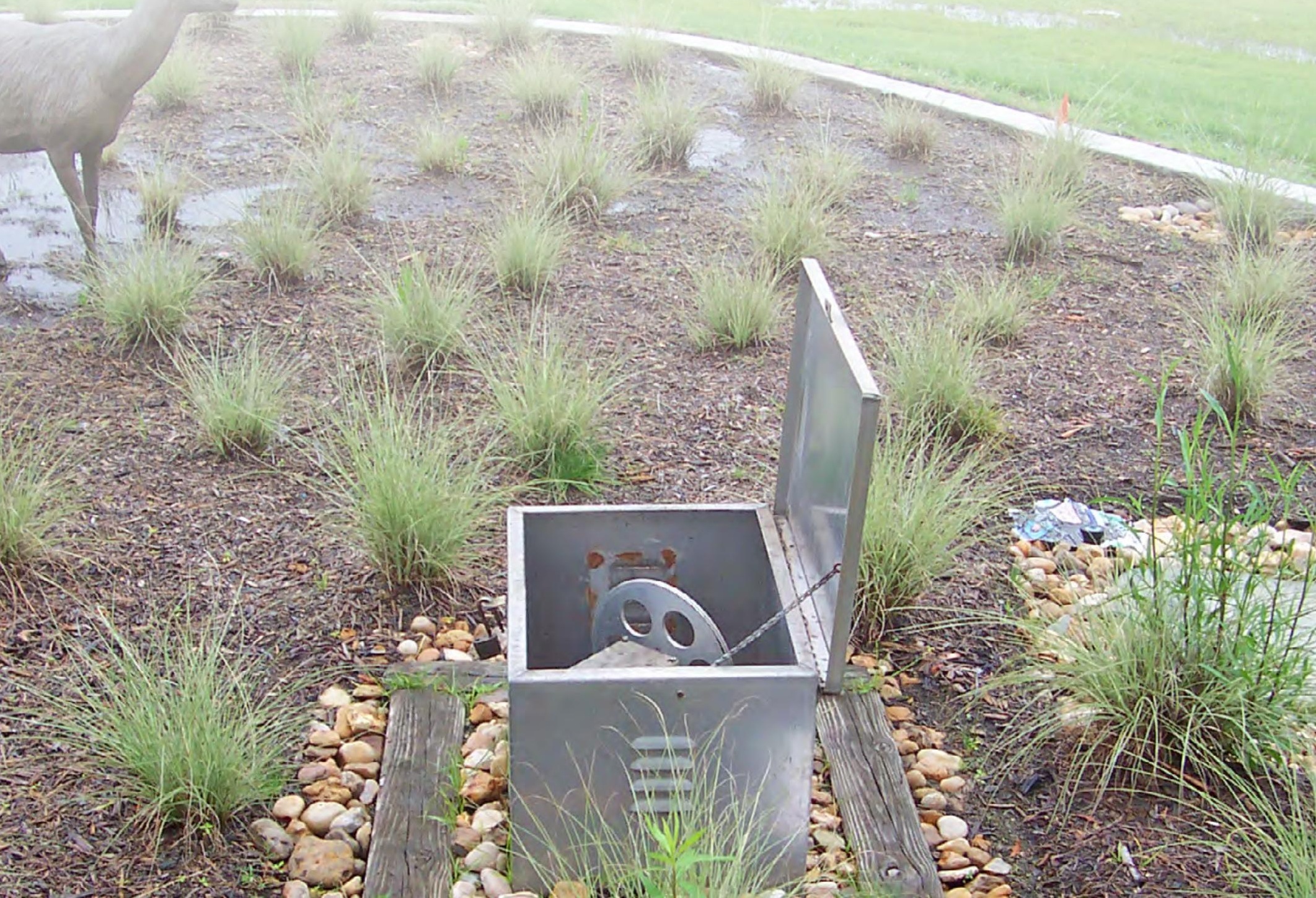




\section{EXPLANATION}

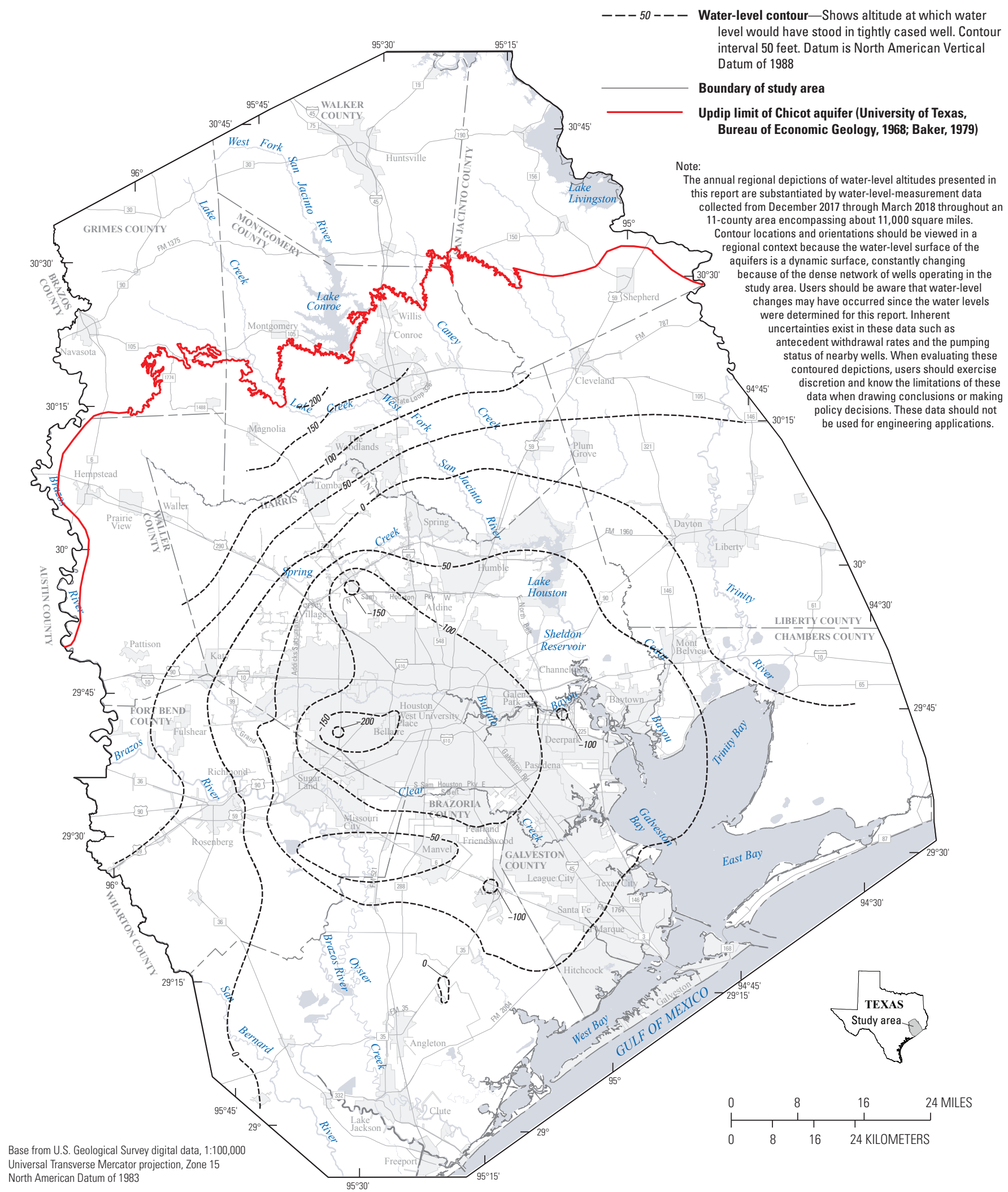

Figure 4. Approximate 2018 groundwater-level altitudes and updip limit of the Chicot aquifer, Houston-Galveston region, Texas (waterlevel-measurement data collected during December 2017 through March 2018). 
EXPLANATION

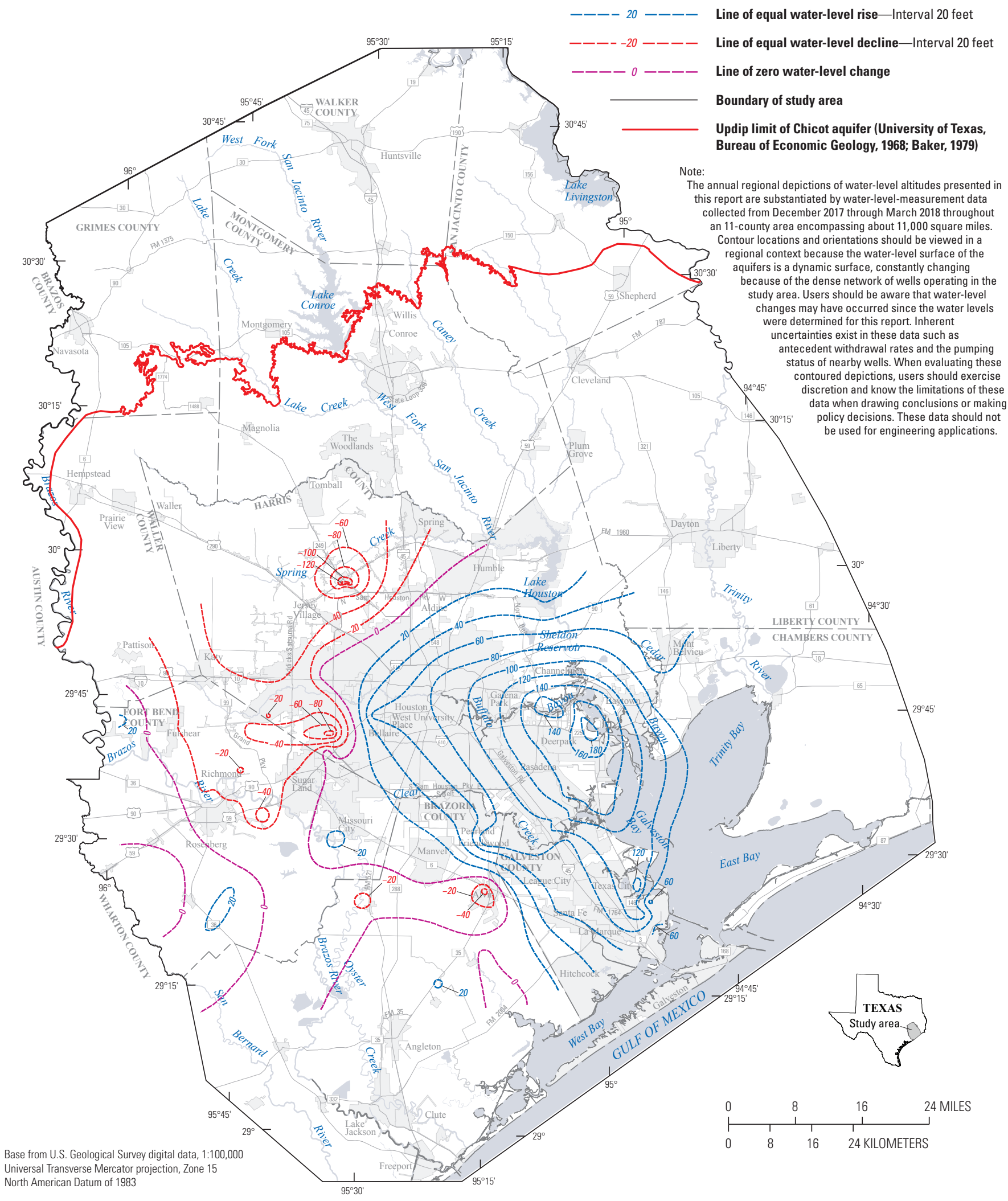

Figure 5. Approximate 1977-2018 groundwater-level changes in the Chicot aquifer, Houston-Galveston region, Texas. 
EXPLANATION

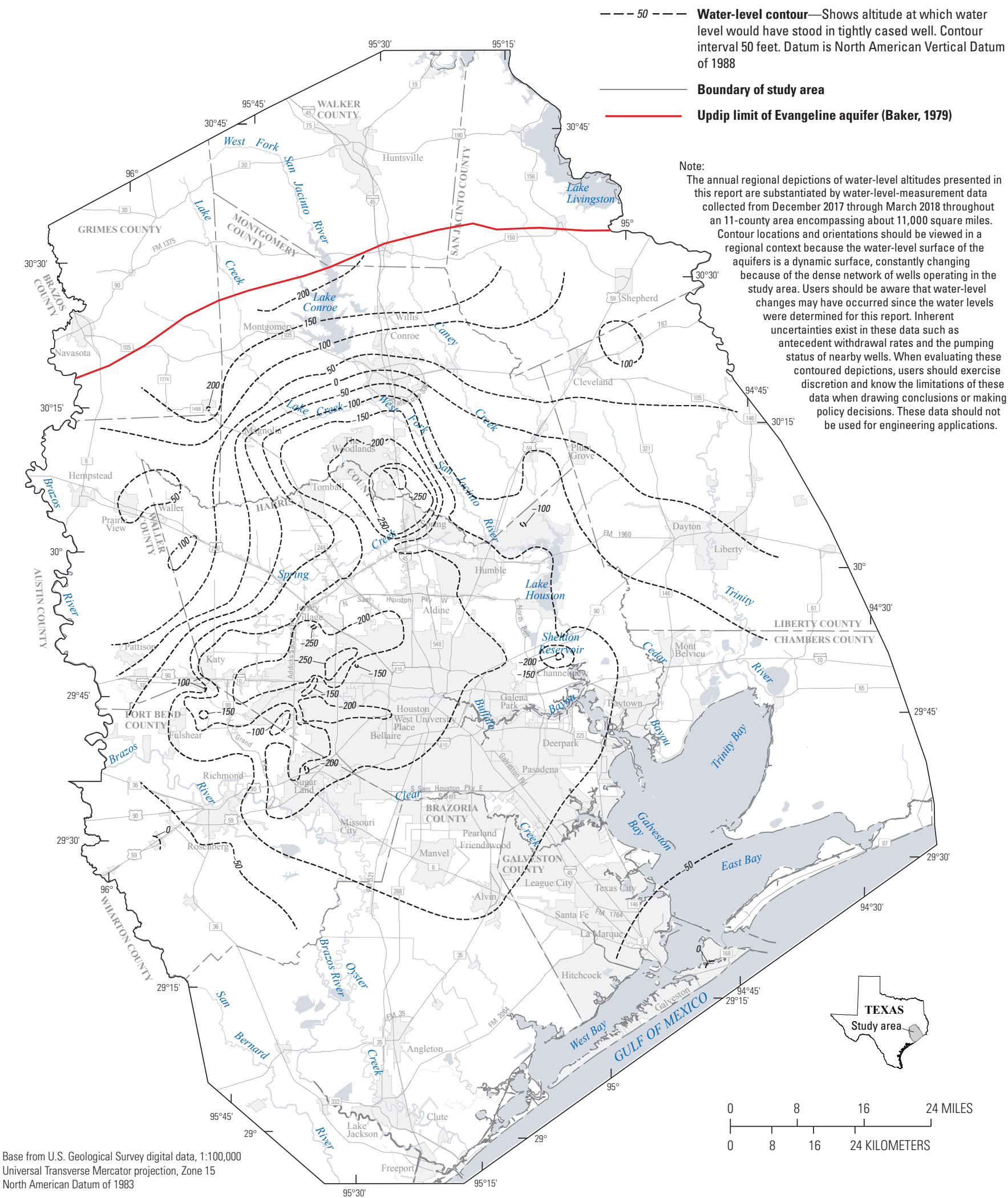

Figure 6. Approximate 2018 groundwater-level altitudes and updip limit of the Evangeline aquifer, Houston-Galveston region, Texas (groundwater-level-measurement data collected during December 2017 through March 2018). 
EXPLANATION

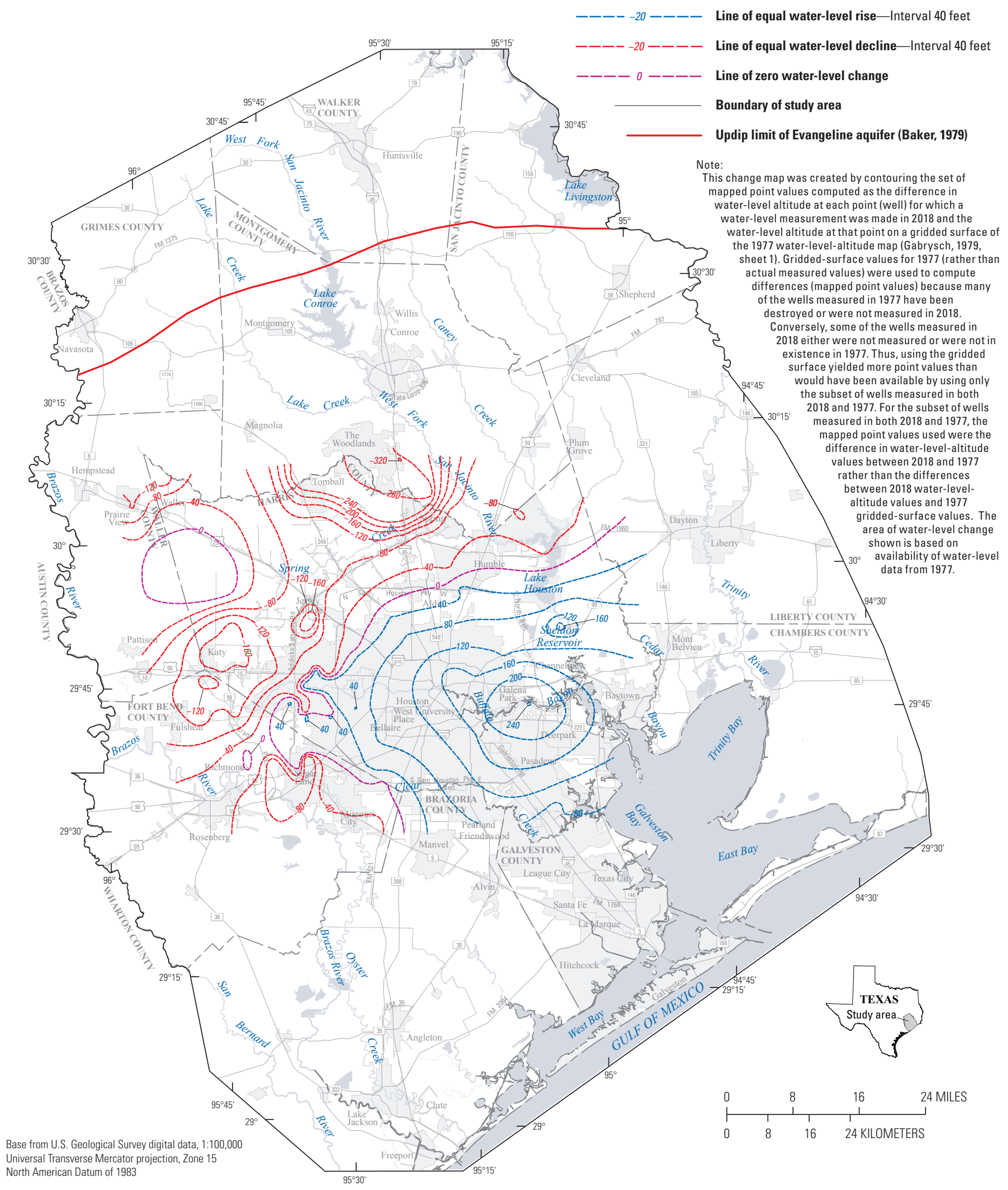

Figure 7. Approximate 1977-2018 groundwater-level changes in the Evangeline aquifer, Houston-Galveston region, Texas. 


\section{EXPLANATION}

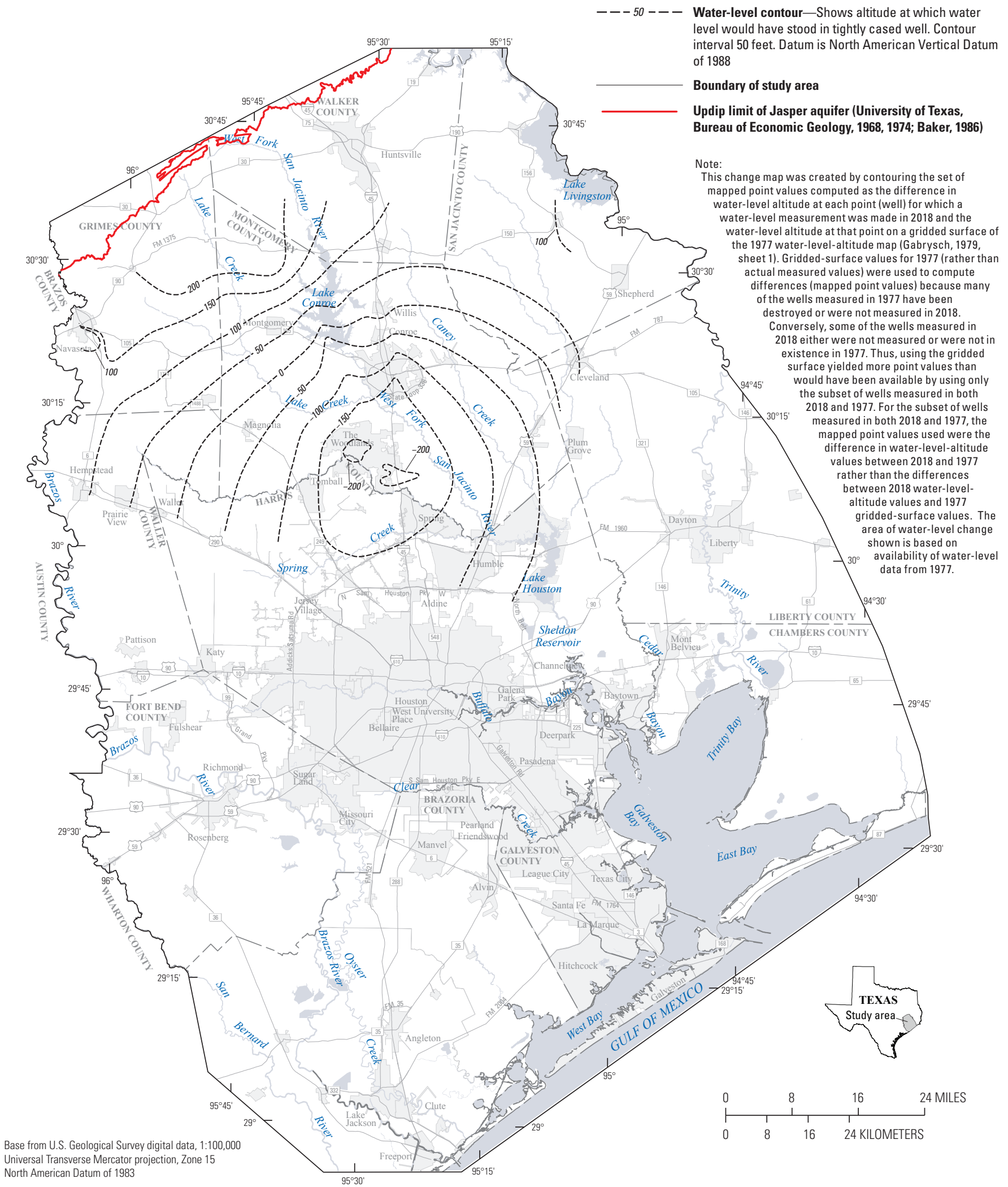

Figure 8. Approximate 2018 groundwater-level altitudes and updip limit of the Jasper aquifer, Houston-Galveston region, Texas (groundwater-level-measurement data collected during December 2017 through March 2018). 
EXPLANATION

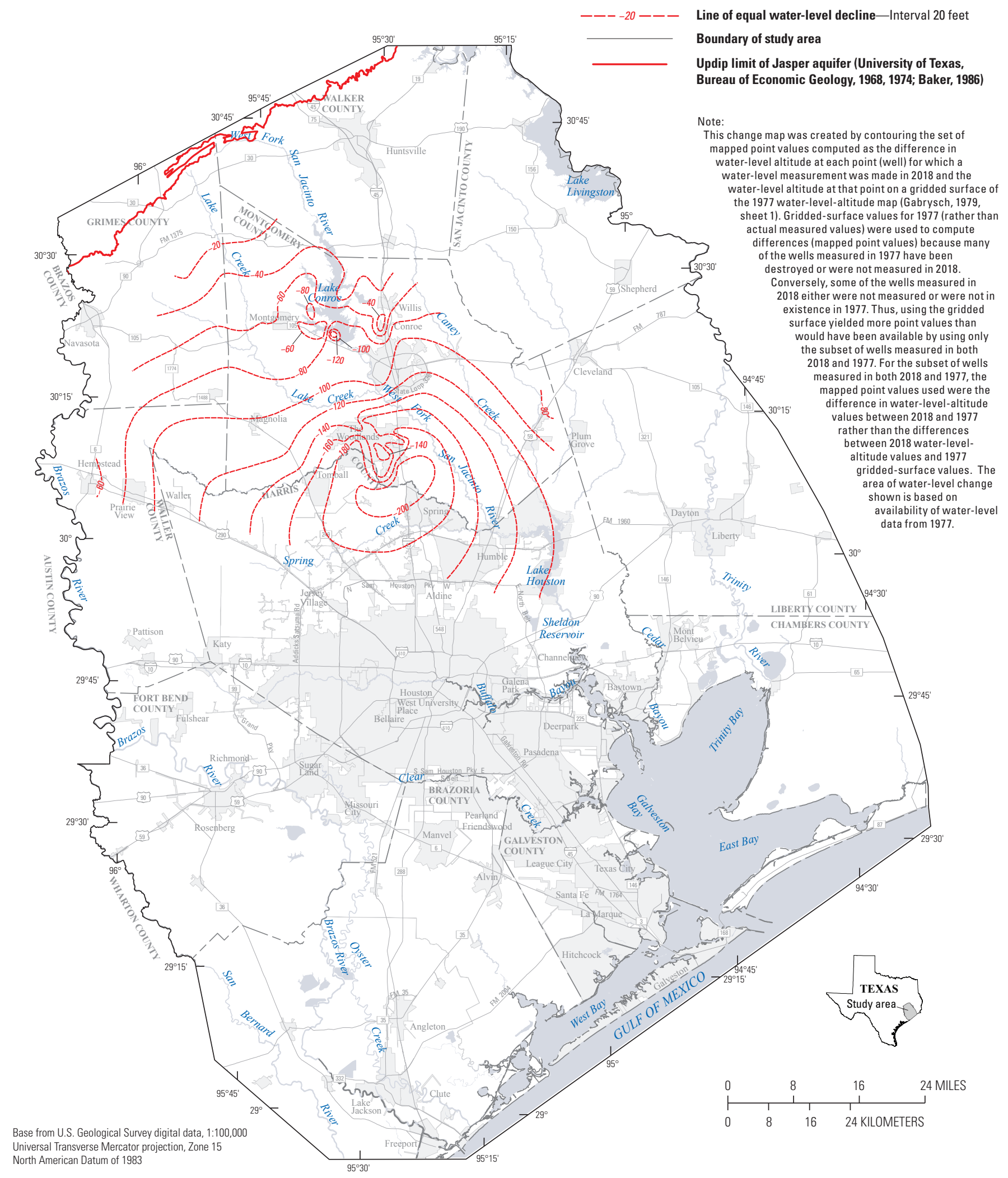

Figure 9. Approximate 2000-18 groundwater-level changes in the Jasper aquifer, Houston-Galveston region, Texas. 


\section{Data Limitations}

As described in the "Methods" section, the accuracy of the land-surface-elevation data has gradually improved over time. Any changes in land-surface elevation could affect the accuracy of groundwater-level-change maps depicting the differences between the current year (2018) and the historical year (1977 or 2000) altitudes (Kasmarek and Ramage, 2017).

The depictions of groundwater-level altitudes and changes at any specific location are considered to represent a regional-scale approximation and, as such, are not intended for use in engineering or other design applications. The groundwater-level altitudes and changes presented in this report were rounded to the nearest foot; the values depicted on the maps represent a mathematical approximation that could vary as much as plus or minus $0.5 \mathrm{ft}$ in addition to accuracies associated with the DEM source data. Users need to exercise discretion when drawing conclusions or making policy decisions on the basis of these contoured depictions.

\section{Summary}

The Houston-Galveston region, Texas, consists of Harris, Galveston, Fort Bend, Montgomery, Brazoria, Chambers, Grimes, Liberty, San Jacinto, Walker, and Waller Counties. Groundwater withdrawn from the three primary aquifers that compose the Gulf Coast aquifer system - the Chicot, Evangeline, and Jasper aquifers - has been the primary source of water for municipal supply, commercial and industrial use, and irrigation in the Houston-Galveston region since the early 1900s. This report, prepared by the U.S. Geological Survey in cooperation with the Harris-Galveston Subsidence District, City of Houston, Fort Bend Subsidence District, Lone Star Groundwater Conservation District, and Brazoria County Groundwater Conservation District, is one in an annual series of reports depicting the status of groundwater-level altitudes and groundwater-level changes in the Chicot, Evangeline, and Jasper aquifers in the Houston-Galveston region. Water levels in wells screened in these aquifers were measured during December 2017 through March 2018 (water levels usually are higher during these months compared to the rest of the year).

This report contains regional-scale maps depicting approximate 2018 groundwater-level altitudes and longterm groundwater-level changes for the Chicot, Evangeline, and Jasper aquifers. Groundwater-level measurements from 172,332 , and 108 wells were used to depict the approximate 2018 groundwater-level-altitude contours for the Chicot, Evangeline, and Jasper aquifers, respectively.

In 2018, groundwater-level-altitude contours for the Chicot aquifer ranged from 200 feet (ft) below the North American Vertical Datum of 1988 (hereinafter referred to as "datum") to $200 \mathrm{ft}$ above datum. The 1977-2018 groundwater-level-change contours for the Chicot aquifer depict a large area of decline in groundwater-level altitudes (120 ft) in northwestern Harris County near Jersey Village, Tex. The largest rise in groundwater-level altitudes in the Chicot aquifer from 1977 to 2018 (180 ft) was in southeastern Harris County between Deer Park, Tex., and Baytown, Tex.

In 2018, groundwater-level-altitude contours for the Evangeline aquifer ranged from $250 \mathrm{ft}$ below datum to $200 \mathrm{ft}$ above datum. The 1977-2018 groundwater-level-change contours for the Evangeline aquifer depict broad areas where groundwater-level altitudes either declined or rose. The largest decline in groundwater-level altitudes $(320 \mathrm{ft})$ was in southern Montgomery County, near The Woodlands, Tex. The largest rise in groundwater-level altitudes in the Evangeline aquifer from 1977 to 2018 (240 ft) was in southeastern Harris County along Buffalo Bayou near Galena Park, Tex.

In 2018, groundwater-level-altitude contours for the Jasper aquifer ranged from $200 \mathrm{ft}$ below datum to $200 \mathrm{ft}$ above datum. Whereas annual groundwater-level-altitude data have been collected since 1977 from wells completed in the Chicot and Evangeline aquifers, annual groundwaterlevel-altitude data have been collected from wells completed in the Jasper aquifer since only 2000 . The $2000-18$ groundwater-level-change contours for the Jasper aquifer depict groundwater-level declines throughout most of the study area where groundwater-level-altitude data from the Jasper aquifer were collected, with the largest decline (200 ft) in southern Montgomery County between Spring, Tex., and The Woodlands.

\section{References Cited}

Arundel, S.T., Archuleta, C.M., Phillips, L.A., Roche, B.L., and Constance, E.W., 2015, 1-meter digital elevation model specification: U.S. Geological Survey Techniques and Methods, book 11, chap. B7, 25 p. with appendixes, accessed July 16, 2018, at http://dx.doi.org/10.3133/ tm11B7.

Baker, E.T., Jr., 1979, Stratigraphic and hydrogeologic framework of part of the Coastal Plain of Texas: Texas Department of Water Resources Report 236, 43 p.

Baker, E.T., Jr., 1986, Hydrology of the Jasper aquifer in the southeast Texas Coastal Plain: Texas Water Development Board Report 295, 64 p.

Barbie, D.L., Coplin, L.S., and Locke, G.L., 1991, Approximate altitude of water levels in wells in the Chicot and Evangeline aquifers in the Houston area, Texas, January-February 1990: U.S. Geological Survey Open-File Report 91-240, 2 sheets, accessed February 10, 2018, at http://pubs.er.usgs.gov/publication/ofr91240. 
Brazoria County Groundwater Conservation District, 2012, Brazoria County Groundwater Conservation District groundwater management plan: Brazoria County Groundwater Conservation District, 76 p., accessed February 10, 2018, at http://www.bcgroundwater. org/images/bcg/documents/BCGCD_Groundwater_ Management_Plan_20121213.pdf.

Carr, J.E., Meyer, W.R., Sandeen, W.M., and McLane, I.R., 1985, Digital models for simulation of ground-water hydrology of the Chicot and Evangeline aquifers along the Gulf Coast of Texas: Texas Department of Water Resources Report 289, $101 \mathrm{p}$.

Chowdhury, A.H., and Turco, M.J., 2006, Geology of the Gulf Coast aquifer, Texas, chap. 2 of Mace, R.E., Davidson, S.C., Angle, E.S., and Mullican, W.F., eds., Aquifers of the Gulf Coast of Texas: Texas Water Development Board Report 365, p. 23-50.

Coplin, L.S., 2001, Water-level altitudes in wells completed in the Jasper aquifer, greater Houston area, Texas, spring 2000: U.S. Geological Survey Open-File Report 01-147, 2 p., accessed February 10, 2018, at http://pubs.usgs.gov/ of/2001/ofr01-147/.

Coplin, L.S., and Galloway, Devin, 1999, Houston-Galveston, Texas-Managing coastal subsidence, in Galloway, Devin, Jones, D.R., and Ingebritsen, S.E., eds., Land subsidence in the United States: U.S. Geological Survey Circular 1182 , p. $35-48$.

Cunningham, W.L., and Schalk, C.W., comps., 2011, Groundwater technical procedures of the U.S. Geological Survey: U.S. Geological Survey Techniques and Methods 1-A1, 151 p., accessed March 15, 2013, at http://pubs.usgs. gov/tm/1a1/.

Fort Bend Subsidence District, 2013, Fort Bend Subsidence District 2003 regulatory plan [amended 2007, 2009, and 2013]: Fort Bend Subsidence District, 15 p., accessed February 10, 2018, at http://fortbendsubsidence.org/ wp-content/uploads/2016/09/FBSD-RegulatoryPlan-20130828.pdf.

Gabrysch, R.K., 1979, Approximate altitude of water levels in wells in the Chicot and Evangeline aquifers in the Houston area, Texas, spring 1977 and spring 1978: U.S. Geological Survey Open-File Report 79-334, 4 sheets.

Harris-Galveston Subsidence District, 2013, Regulatory plan 2013: Harris-Galveston Subsidence District, 14 p., accessed February 10, 2018, at http://hgsubsidence.org/wp-content/ uploads/2013/07/HGSD-2013-Regulatory-Plan-withAmendment.pdf.
Johnson, M.R., Ramage, J.K., and Kasmarek, M.C., 2011, Water-level altitudes 2011 and water-level changes in the Chicot, Evangeline, and Jasper aquifers and compaction 1973-2011 in the Chicot and Evangeline aquifers, HoustonGalveston region, Texas: U.S. Geological Survey Scientific Investigations Map 3174, 17 p., 16 sheets, accessed February 10, 2018, at https://pubs.usgs.gov/sim/3174/.

Kasmarek, M.C., 1997, Water-level altitudes in wells completed in the Chicot and Evangeline aquifers, Fort Bend County and adjacent areas, Texas, January-March 1990: U.S. Geological Survey Open-File Report 97-784, 2 sheets, accessed February 10, 2018, at https://pubs.er.usgs.gov/ publication/ofr97784.

Kasmarek, M.C., 2013, Hydrogeology and simulation of groundwater flow and land-surface subsidence in the northern part of the Gulf Coast aquifer system, Texas, 1891-2009 (ver. 1.1, December 2013): U.S. Geological Survey Scientific Investigations Report 2012-5154, 55 p., accessed February 10, 2018, at http://pubs.usgs.gov/ $\operatorname{sir} / 2012 / 5154 /$.

Kasmarek, M.C., and Houston, N.A., 2007, Water-level altitudes 2007 and water-level changes in the Chicot, Evangeline, and Jasper aquifers and compaction 19732006 in the Chicot and Evangeline aquifers, HoustonGalveston region, Texas: U.S. Geological Survey Scientific Investigations Map 2968, 159 p., 18 sheets, accessed February 10, 2018, at http:/pubs.usgs.gov/sim/2007/2968/.

Kasmarek, M.C., and Houston, N.A., 2008, Water-level altitudes 2008 and water-level changes in the Chicot, Evangeline, and Jasper aquifers and compaction 19732007 in the Chicot and Evangeline aquifers, HoustonGalveston region, Texas: U.S. Geological Survey Scientific Investigations Map 3031, 4 p., 17 sheets, accessed February 10, 2018, at http://pubs.usgs.gov/sim/3031/.

Kasmarek, M.C., Houston, N.A., and Brown, D.W., 2006, Water-level altitudes 2006 and water-level changes in the Chicot, Evangeline, and Jasper aquifers and compaction 1973-2005 in the Chicot and Evangeline aquifers, HoustonGalveston region, Texas: U.S. Geological Survey Open-File Report 2006-1079, 15 sheets, accessed February 10, 2018, at https:/pubs.usgs.gov/of/2006/1079/.

Kasmarek, M.C., Houston, N.A., and Ramage, J.K., 2011, Water-level altitudes 2009 and water-level changes in the Chicot, Evangeline, and Jasper aquifers and compaction 1973-2008 in the Chicot and Evangeline aquifers, HoustonGalveston region, Texas (ver. 1.3, March 15, 2011): U.S. Geological Survey Scientific Investigations Map 3081, 3 p., 16 sheets, 2 apps., accessed February 10, 2018, at https:// pubs.usgs.gov/sim/3081/. 
Kasmarek, M.C., Johnson, M.R., and Ramage, J.K., 2010, Water-level altitudes 2010 and water-level changes in the Chicot, Evangeline, and Jasper aquifers and compaction 1973-2009 in the Chicot and Evangeline aquifers, HoustonGalveston region, Texas: U.S. Geological Survey Scientific Investigations Map 3138, 17 p., 16 sheets, 1 app., accessed February 10, 2018, at http://pubs.usgs.gov/sim/3138/.

Kasmarek, M.C., Johnson, M.R., and Ramage, J.K., 2012, Water-level altitudes 2012 and water-level changes in the Chicot, Evangeline, and Jasper aquifers and compaction 1973-2011 in the Chicot and Evangeline aquifers, HoustonGalveston region, Texas: U.S. Geological Survey Scientific Investigations Map 3230, 18 p., 16 sheets, accessed February 10, 2018, at http://pubs.usgs.gov/sim/3230/.

Kasmarek, M.C., Johnson, M.R., and Ramage, J.K., 2013, Water-level altitudes 2013 and water-level changes in the Chicot, Evangeline, and Jasper aquifers and compaction 1973-2012 in the Chicot and Evangeline aquifers, HoustonGalveston region, Texas: U.S. Geological Survey Scientific Investigations Map 3263, 19 p., 16 sheets, accessed February 10, 2018, at http://pubs.usgs.gov/sim/3263/.

Kasmarek, M.C., Johnson, M.R., and Ramage, J.K., 2014, Water-level altitudes 2014 and water-level changes in the Chicot, Evangeline, and Jasper aquifers and compaction 1973-2013 in the Chicot and Evangeline aquifers, HoustonGalveston region, Texas: U.S. Geological Survey Scientific Investigations Map 3308, 20 p., 16 sheets, accessed February 10, 2018, at https://dx.doi.org/10.3133/sim3308.

Kasmarek, M.C., and Lanning-Rush, Jennifer, 2004, Waterlevel altitudes 2004 and water-level changes in the Chicot, Evangeline, and Jasper aquifers and compaction 1973-2003 in the Chicot and Evangeline aquifers, Houston-Galveston region, Texas: U.S. Geological Survey Open-File Report 2004-1084, 13 sheets, accessed February 10, 2018, at http:// pubs.usgs.gov/of/2004/1084/.

Kasmarek, M.C., and Ramage, J.K., 2017, Water-level altitudes 2017 and water-level changes in the Chicot, Evangeline, and Jasper aquifers and compaction 19732016 in the Chicot and Evangeline aquifers, HoustonGalveston region, Texas: U.S. Geological Survey Scientific Investigations Report 2017-5080, accessed February 10, 2018, at http://dx.doi.org/10.3133/sir20175080.

Kasmarek, M.C., Ramage, J.K., Houston, N.A., Johnson, M.R., and Schmidt, T.S., 2015, Water-level altitudes 2015 and water-level changes in the Chicot, Evangeline, and Jasper aquifers and compaction 1973-2014 in the Chicot and Evangeline aquifers, Houston-Galveston region, Texas: U.S. Geological Survey Scientific Investigations Map 3337 , pamphlet, 16 sheets, scale 1:100,000, accessed February 10, 2018, at https://dx.doi.org/10.3133/sim3337.
Kasmarek, M.C., Ramage, J.K., and Johnson, M.R., 2016, Water-level altitudes 2016 and water-level changes in the Chicot, Evangeline, and Jasper aquifers and compaction 1973-2015 in the Chicot and Evangeline aquifers, HoustonGalveston region, Texas: U.S. Geological Survey Scientific Investigations Map 3365, pamphlet, 16 sheets, scale 1:100,000, accessed February 10, 2018, at http://dx.doi. org/10.3133/sim 3365 .

Kasmarek, M.C., and Robinson, J.L., 2004, Hydrogeology and simulation of ground-water flow and land-surface subsidence in the northern part of the Gulf Coast aquifer system, Texas: U.S. Geological Survey Scientific Investigations Report 2004-5102, 111 p., accessed February 10, 2018, at http://pubs.usgs.gov/sir/2004/5102/.

Lambeck, Kurt, Esat, T.M., and Potter, Emma-Kate, 2002, Links between climate and sea levels for the past three million years: Nature, v. 419, no. 6903, p. 199-206, accessed February 10, 2018, at http://www.nature.com/ nature/journal/v419/n6903/full/nature01089.html.

Lone Star Groundwater Conservation District, 2013, District regulatory plan phase II (B): Lone Star Groundwater Conservation District, 24 p., accessed July 5, 2018, at https://static1.squarespace.com/ static/58347802cd0f6854e2f90e45/t/585c0aa3e6f2e1d 6a2c7a372/1482427044244/DRP-Phase-IIB-clean-asamended-12.8.15-.pdf.

Meyer, W.R., and Carr, J.E., 1979, A digital model for simulation of ground-water hydrology in the Houston area, Texas: Texas Department of Water Resources LP-103, 27 p.

National Oceanic and Atmospheric Administration, 2008, The elements of geodesy_-The vertical datum: National Oceanic and Atmospheric Administration, accessed February 10, 2018, at http:/oceanservice.noaa.gov/education/kits/ geodesy/geo06_vertdatum.html.

Sellards, E.H., Adkins, W.S., and Plummer, F.B., 1932, The geology of Texas, volume 1-Stratigraphy: The University of Texas Bulletin 3232, 1,007 p.

Shah, S.D., and Ramage, J.K., 2018a, Depth to groundwater measured from wells completed in the Chicot, Evangeline, and Jasper aquifers, Houston-Galveston region, Texas, 2018: U.S. Geological Survey data release, https://doi. org/10.5066/F79S1QBW.

Shah, S.D., and Ramage, J.K., 2018b, Groundwater-level altitudes and long-term groundwater-level changes in the Chicot, Evangeline, and Jasper aquifers, Houston-Galveston region, Texas, 2018: U.S. Geological Survey data release, https://doi.org/10.5066/P9FEL6MS. 
Strom, E.W., Houston, N.A., and Garcia, C.A., 2003a, Selected hydrogeologic datasets for the Chicot aquifer, Texas: U.S. Geological Survey Open-File Report 03-297, 1 CD-ROM.

Strom, E.W., Houston, N.A., and Garcia, C.A., 2003b, Selected hydrogeologic datasets for the Evangeline aquifer, Texas: U.S. Geological Survey Open-File Report 03-298, 1 CD-ROM.

Strom, E.W., Houston, N.A., and Garcia, C.A., 2003c, Selected hydrogeologic datasets for the Jasper aquifer, Texas: U.S. Geological Survey Open-File Report 03-299, 1 CD-ROM.

University of Texas, Bureau of Economic Geology, 1968, Geologic atlas of Texas, Beaumont sheet: Austin, University of Texas, Bureau of Economic Geology, scale 1:250,000.

University of Texas, Bureau of Economic Geology, 1974, Geologic atlas of Texas, Austin sheet: Austin, University of Texas, Bureau of Economic Geology, scale 1:250,000.

U.S. Geological Survey, 2018a, 3D Elevation Program (3DEP) - Introduction and goals: U.S. Geological Survey, National Geospatial Program, accessed May 22, 2018, at http://nationalmap.gov/3DEP/index.html.

U.S. Geological Survey, 2018b, National Water Information System-USGS water data for the Nation: U.S. Geological Survey, accessed March 20, 2018, at http://dx.doi. org/10.5066/F7P55KJN.

Worboys, M.F., 1995, GIS-A computer science perspective: London, Taylor and Francis, 376 p.

For more information about this publication, contact

Director, Texas Water Science Center

U.S. Geological Survey

1505 Ferguson Lane

Austin, TX 78754-4501

For additional information visit https://tx.usgs.gov/.

Publishing support provided by

Lafayette Publishing Service Center 


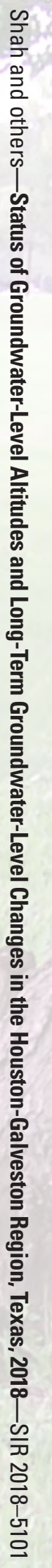

